Paper accepted for publication (the version below is the final version prior to proof). The paper was eventually published in Asia Pacific Business Review, 2015, Vol. 21, no. 1, January, pp. 1-9, DOI: 10.1080/13602381.2014.939887.

\title{
MANAGING CHINA'S ENERGY SECTOR: Between the market and the state
}

\section{Hongyi Lai*,}

Faculty of Social Sciences,

University of Nottingham,

Nottingham

NG8 1BB

and

\section{Malcolm Warner,}

Judge Business School,

University of Cambridge,

Cambridge,

CB2 IAG

*EMAIL: Hongyi.Lai@nottingham.ac.uk

\begin{abstract}
As China has now become the largest energy consumer in the world, its energy sector has understandably huge domestic and global implications. In this Special Issue, which is an interdisciplinary one, comprising a set of eight in-depth empirical studies by leading international experts in the field, we set out to examine the management of the transformation of China's conventional and renewable energy sectors, with special attention to state-business relations and their link to the market.
\end{abstract}

\section{Keywords}

Asia, China, economics, energy, environment, pollution 


\section{Introduction}

We will here attempt to place the theme of this Special Issue on Managing China's Energy Sector in its historical and contemporary context, as well as its economic, political and social importance, to not only in the People's Republic of China (PRC) and the rest of Asia but also the wider global economy. The Chinese economy has grown at a relentless rate, around ten percent per annum, since the economic reforms were introduced by Deng Xiaoping in 1978 (see Warner 2014). As a result, it has become the number-two economic global superpower (see Aoki and Wu 2012). According to a recent World Bank study, China could surpass the United States to be the largest economy in the purchase power parity term in 2014 (FT 2014).

To sum up, as China has now become the largest energy consumer and is viewed by analysts as the largest carbon dioxide emitter and recently the largest net oil importer in the world, its energy sector has understandably huge domestic implications, as well as for the global economy. In this Special Issue comprising an introduction, eight empirical studies all by leading international experts in the field, and a conclusion we set out to examine the management and transformation of China's conventional and renewable energy sectors, with special attention to state-business relations and its links to the market. As a start, two studies examine the development of China's energy profile and especially China's renewable energy. They highlight China's massive efforts to promote renewable energy such as hydro, solar, wind, and geo-thermal power, as well as cleaner conventional energy sources such as natural gas, in order to reduce pollution and $\mathrm{CO} 2$ emissions. Meanwhile, the authors of these studies acknowledge the continuous predominance of conventional energy sources such as coal and oil in China. Another two studies are devoted to the governmental relations with state-owned enterprises (SOEs) and the reform of these SOEs. Despite drastic restructuring in the late 1990s, these firms continue their oligopolistic control of the oil and gas sectors and even overshadow the stock market. It was found that the government has even failed to act as a 'principal' and keep its 'agents', namely, largest oil and gas state firms, under its control. An analysis of the corporate performance of these firms suggests the limits of the improvement of corporate governance. For example, national oil and petrochemical companies (NOPCs) were found to shun external financial markets and supervision and to rely more on ineffectual finance markets during 2007-2011. The next three studies investigate the factors that help propel the expansion of China's conventional energy firms (i.e., oil and gas firms) and firms producing renewable energy technology (i.e., solar PV industry). The analyses of the major international merger and acquisition deals of the two largest oil companies in China suggest that that these companies tend to choose the down/upstream sectors that they have specialized in inking of these deals and that strategic assets-seeking has gained increasing significance. A study of China's solar PV industry further suggests that China's governmental support for the industry has evolved from subsidising the production side (a 'mercantile' stage aiming at expanding the industry's global share of production and exports) to subsiding the demand side (aiming at expanding domestic demand and absorbing redundant manufacture capacity). As a result, China could witness an exponential rapid growth in its PV installed capacity in the near future. Another study of China's solar PV industry finds that firms in this industry tend to pay heavy attention to extra-firm institutional network relationships, both 
within and outside of China and that buyer-supplier networks are spatially influenced by extra-local managerial education. Firms with internationally educated managers in turn tend to have more non-Mainland Chinese managers, circumventing traditional management practices at home. The last empirical study in this Special Issue examines the per capita embedded carbon footprints in urban China, among China's provinces from a consumption perspective, by resorting to a self-organizing feature map (SOFM) model. The research finds that the per capita ECF of the east coastal area reaches a high level and that per capita disposable income determines ECF.

\section{Contributions}

The contributors to this volume, a number of whom are originally of Chinese origins and affiliations, hail from a number of countries across the globe, including Australia, Singapore, South Korea, United Kingdom and so on and from many universities and business schools. The authors are all leading international experts in their fields of study, as they relate to the energy sector policies of the 'Middle Kingdom'.

A set of summaries of the respective contributions to the Special Issue follows. They will be set out in the order in which they appear.

In Table 1, we list the titles of the contributions and the topics which will be covered by their respective authors. 
Table 1. Titles, Topics and Authors of the Contributions in the Special Issue

\begin{tabular}{|l|l|l|}
\hline Contribution Title & Topic & Authors \\
\hline $\begin{array}{l}\text { The Role of Oil and Gas in China's Energy Strategy: } \\
\text { An Overview }\end{array}$ & $\begin{array}{l}\text { Development and } \\
\text { diversification of energy profile }\end{array}$ & $\begin{array}{l}\text { Elspeth Thomson; Augustin } \\
\text { Boey }\end{array}$ \\
\hline $\begin{array}{l}\text { China's Renewable Energy Development: Policy, } \\
\text { Industry and Business Perspectives }\end{array}$ & $\begin{array}{l}\text { Development and pattern of } \\
\text { China's renewable energy }\end{array}$ & Christopher Dent \\
\hline $\begin{array}{l}\text { The Chinese Government and the National Oil } \\
\text { Companies (NOCs): Who Is the Principal? }\end{array}$ & $\begin{array}{l}\text { Reform of large national state- } \\
\text { owned enterprises (SOEs) and } \\
\text { SOEs-state relations }\end{array}$ & Janet Xuanli Liao \\
\hline $\begin{array}{l}\text { Corporate Governance or Governance by } \\
\text { Corporates? Testing Governmentality in the Context } \\
\text { of China's National Oil and Petrochemical Business } \\
\text { Groups }\end{array}$ & $\begin{array}{l}\text { Reform and corporate } \\
\text { governance of national SOEs }\end{array}$ & Tyler Rooker \\
\hline $\begin{array}{l}\text { Rationale of internationalisation of China's NOCs: } \\
\text { Seeking Natural Resources, Strategic Assets, or } \\
\text { Sectoral Specialisation? }\end{array}$ & $\begin{array}{l}\text { Pattern and rationale of } \\
\text { overseas investment of China's } \\
\text { major energy firms }\end{array}$ & $\begin{array}{l}\text { Hongyi Lai, Sarah O'Hara, and } \\
\text { Karolina Wysoczanska }\end{array}$ \\
\hline $\begin{array}{l}\text { From Mercantile Strategy to Domestic Demand } \\
\text { Stimulation: Changes in China's Solar PV Subsidies }\end{array}$ & $\begin{array}{l}\text { State subsidies and domestic } \\
\text { and international markets of } \\
\text { China's Solar PV industry }\end{array}$ & Gang Chen \\
\hline $\begin{array}{l}\text { Enrolling in Global Networks and Contingencies for } \\
\text { China's Solar PV Industry }\end{array}$ & $\begin{array}{l}\text { Global networks and expansion } \\
\text { of China's solar PV industry }\end{array}$ & Douglas Gress \\
\hline $\begin{array}{l}\text { Regional Disparity of Embedded Carbon Footprint } \\
\text { and Its Sources in China: A Consumption } \\
\text { Perspective }\end{array}$ & $\begin{array}{l}\text { Spatial differentiation of per } \\
\text { capita embedded carbon } \\
\text { footprint (ECF) in urban China } \\
\text { and key determinants }\end{array}$ & $\begin{array}{l}\text { Jin Fan, Yanrui Wu, Xiumei } \\
\text { Guo, Dingtao Zhao and Dora } \\
\text { Marinova }\end{array}$ \\
\hline
\end{tabular}

\section{INSERT TABLE 1 ABOUT HERE.}

The Editors first go on to outline the main topics in the Special Issue of the APBR. The studies contained all deal with the management of China's energy sector. They all focus on the main strategy in play but at the same time each take a different perspective from the view of the different disciplines or mix of such represented. Summaries of the contributions are presented in the order in which they appear in the Symposium.

Up-front is the contribution by Thompson and Boey (2015) deals with the role of oil and gas in China's energy strategy. As a general overview, it sets the scene for the many themes raised in the Special issue. These are of enormous importance in the international economy. Like all of the world's geographically large countries, it argues, China is clearly well endowed with energy- resources. The Middle Kingdom has large quantities of coal, oil, gas and hydro-power, as well as significant solar, wind and biomass energy-potential and even has its own uranium. To date, China has relied for the most part on coal and hydropower to generate its electricity, and on oil to power its transport. However, with 'climate change' and its accompanying rising sea--levels, increased levels of drought, intense storms, increasing frequencies of heat waves, and so on, China, having become the world's largest emitter of $\mathrm{CO} 2$, is under increasing international pressure to re-examine its energy strategy and find ways to cut its carbon emissions. Most recently, the Copenhagen conference renewed the pressure on it to revise its position. Thus, the government is planning to increase its utilization of natural gas in its power-generation as gas emits less than half the $\mathrm{CO} 2$ than coal. The authors argue here that over the next two decades, massive imports of gas via pipeline and LNG tankers, together 
with the development of unconventional gas reserves in the country may in part substitute for the huge quantities of coal now being used to generate electricity, but will not likely completely replace them. All this will take time for the national configuration to adjust and change. As for transportrelated fuels, China, like all other nations, has little choice but to keep on relying on oil no matter whether it is imported or the PRC build-up its own large-scale shale-oil operations. There appears to be, they continue, no alternate fuel of the same density available at the same or better price. The use of biofuels and electric/hybrid vehicles will not realistically supplant the use of gasoline or diesel. Thus, the role of oil and gas in China's energy strategy, they conclude, are set to remain very critical over the next couple of decades.

The insightful contribution by Dent (2015) that follows, deals with China's renewable energy development, in terms of policy, industry and business perspectives. It reveals how China has been at the forefront of the recent global expansion of 'renewable energy' (RE) activity, an enormous step for a country, which although it has grown at a relentless pace economically, is still on the road to development. This study examines how the country has achieved its position as the world's largest producer and exporter of RE products, and biggest power-generator from renewables. This holds out great prospect for future economic growth. Certainly, this represents a major achievement not only in East Asia but also globally. More specifically, the study explores the main motives pushing forward renewable energy-development in China, how this is embedded in broader new development thinking on realising 'ecological civilisation' goals as they are described, evolving government policies on strategic planning on renewables, as well as the complex multi-layered landscape of China's renewable energy business. Here, various categories of state-owned enterprises (SOEs) collaborate and compete among each other, alongside a large number of private companies, especially in equipment-manufacturing. All in all, a fascinating complex set of economic and organizational possibilities.

Next, the highly relevant study by Liao (2015) deals with the relationship between the Chinese government and the national oil companies (Nocs) and asks 'who is the principal?'. It sets out to describe how China has conducted six major governmental reforms over the past three decades to separate government functions from the key industries, which brought a number of state-owned, national oil companies (NOCs) into being in the 1980s, and then listed in the international stock markets in the century after. Prima facie, this was a very significant policy initiative. However, due to the incomplete governmental and enterprise reforms, the authors argue that the government has not has not been very successful as the 'principal' to make the NOCs an effective 'agent' to manage China's petroleum industry on its behalf. The study then goes into further detail about the notion of 'principal'. Since it seems unlikely for Beijing to change the ownership of the NOCs, there are two possible options to reinforce the 'principal-agent' relationship. One is to further remove the NOCs' political functions, and to boost China's energy market mechanism. Once there is a better environment for market competitions, they continue, it could be more sensible for the government to cut short its direct intervention in fuel price-setting, and in market operations. The other alternative, they argue, is to set up an Energy Ministry that can assert absolute authority over the NOCs, and to manage the whole energy sector via a more coherent and effective incentive system. This incisive piece concludes by looking at the two possible remedies of the state-NOCs relations. 
After this, the contribution by Rooker (2015) asks whether there is corporate governance or governance by corporates, testing the governmental logic in the context of China's national oil and petrochemical business groups. Like other industrial sectors with significant-'pillar'-importance to China's overall economy and development, oil and petrochemicals are governed by state-owned business groups. In this context, 'corporate governance' of these groups is of fundamental interest. This study probes corporate governance of 31 national oil and petrochemical business groups in the PRC by examining their structure, development and business activities over the period from 2007 to 2011. The post-1998 restructuring of China's qiye jituan which are business groups like Korean chaebols, their related Party transactions and related Party corporate finance all yield insights into how property rights are critical in shaping how corporate governance based on 'governmentality'or the interrelation of corporate, state and social relations-is effectively structured. This fascinating contribution sheds light on how China's big business policy and governance of the state-business interface works in a 'socialist market' economy. This contribution more broadly clearly has key implications for international trade and investment, as well as multinational corporations doing business with the PRC. It is a useful study for understanding the complexity of the relations between the partners involved in the above linkages.

The next essay by Lai, O'Hara, and Wysoczanska (2015) on deciding between strategic assets or natural resources focuses on what has been dubbed the 'Going-Out' of China's oil and gas corporations. The bulk of the existing literature, it argues, has emphasised that China's companies seek strategic assets (technology, brands, and access to markets) through internationalization, mainly in order to overcome late-comers' comparative disadvantage, while some studies they suggest think that these firms sought natural resources to address China's rising oil imports. The third argument (which they coin the 'sectoral strength' hypothesis) suggested that the up-stream firms in extractive business would seek natural resources and good infrastructure, whereas downstream one would seek strategic assets and efficiency. In this article, the authors look in depth at the rationale of main overseas investment deals ('going out') of China's two largest national oil companies during 2002-2010 which were also the top two outward investing Chinese firms in 2010. They conclude that these deals can be best explained by the 'sectoral specialisation' hypothesis, supplemented with a consideration for strategic assets.

The study by Chen (2015) which follows looks at the switch from what the authors call the mercantile strategy to domestic demand stimulation, dealing with changes in China's solar PV subsidies. Through looking in depth at China's industrial subsidies towards its solar PV sector from a theoretical perspective constructed by the renowned Harvard-based strategic thinker, Michael Porter, on the government's role in forging national comparative advantages, this important contribution attempts to take a snapshot of the recent dynamics in China's state capitalism, which has been evolving from a mercantile stage in which most subsidies were designed to influence factor conditions and supporting industries, on to a new phase of domestic demand with more subsidies aimed at reshaping domestic demand conditions to absorb redundant manufacture capacity. China has lately emerged as the world's largest solar panel producer, but, compared to its fast-expanding 
wind power market that has many advantages in attracting policy support, China's domestic solar PV market has been underdeveloped and has been unable to absorb a sizeable element of its inflated production capacity. Empirical evidences have shown that, in sync with the state's recent policy shift to domestic demand from export-orientated mercantile strategy, the government's role in supporting the solar PV industry has been transforming from subsidizing the production side to subsiding the demand side. As solar PV power generation is fast coming to the breaking point of grid- parity with existing subsidies and feed-in tariffs, China could soon see its PV installed capacity expand exponentially in the coming future. This is a useful piece which adds to knowledge in the field.

Next, the contribution by Gress (2015) deals with the issue of firms 'enrolling' in global networks and how this may impact broader contingencies related to firm activity in the solar industry of the PRC. More specifically, this contribution tests the contention in the Asian business systems literature that interacting with global managers and increasing experience via international education are possible ways by which Asian firms enrol in global networks, thus potentially leading to changes in their broader network contingencies. Solar PV firms are examined in the study given the competitiveness of Chinese products in the global marketplace and the importance being placed on solar energy domestically as China confronts increasing pressure to better look after its environment and control pollution, whilst at the same time accommodating mounting energy needs. The upshot of the contribution suggests that an emphasis on extra-firm institutional network relationships, both within and outside of China, for all players is characteristic of a bourgeoning energy sector. A unique result, the research also finds, is that buyer-supplier networks are spatially influenced by extra-local managerial education. Enrolling in wider networks, Gress (2015) concludes, is also important in this context, as firms with internationally educated managers have more non-Mainland Chinese managers, which may mitigate traditional management practices at home. All in all, this proves to be a most insightful contribution.

The final empirical study by Fan, Wu, Guo, Zhao and Marinova (2015) examines in depth the theme of regional disparity of embedded carbon footprint and its sources in China from the consumption perspective. Carbon emission reduction could, the authors argue, be achieved through extensive cooperation between relevant groups such as businesses, governments and consumers. Overall, they continue, carbon emissions stem from consumer behaviour. To effectively deal with the increasingly serious energy crisis and climate change in China, it is thus critical to control carbon emissions generated by the country's urban consumers. From a consumption perspective, as the authors put it, they utilize a self-organizing feature map (SOFM) model to analyse the spatial differentiation of per capita embedded carbon footprint (ECF) in urban China. The researchers found that the 'spatial differentiation' has been shown to be significant with the per capita ECF of the east coastal area at a high level and that per capita disposable income is the key factor affecting ECF. Based on these findings, they conclude, potential business opportunities to develop low-carbon products may be considered. 
Last, the Editors of this Special Issue offer their Concluding Remarks concerning the upshot of the research published here. They then go on to evaluate the findings the authors have respectively put forward, in the light of the central themes of the Issue.

\section{Discussion}

The theme of 'global warming' is the most general of dimensions to take into account in concentrating one's mind of the issues we present here, as is also the growing pollution to be witnessed across the nation which has now become a 'negative' charge of China's growth. Since potential constraints on economic growth per se for China may occur when constraints on energy supplies occur, this aspect is another key one to emphasize in this review of the topic.

It will be seen that the above contributions each pinpoint relevant connections to the above generalities in the Special issue, to focus it on the managing of China's energy sector. The studies look at respectively economic, political, strategic, as well as structural dimensions in particular detail, relating it to policy. They provide much-needed insights on three topics, namely, the economic and corporate development of the energy sector, domestic energy policies, and energy security in China.

There has been a limited yet growing literature on these three topics. Regarding the first aforementioned topic, namely, the development of the energy sector in China, several existing studies, which tend to be comprehensive and historically-based, document the history of the reform of state energy firms, the growth of the energy sector in the pre-reform era, the transformation of the energy sector since 1978, the role of energy in economic growth, energy demand and supply, and profile of China's energy (IEA 2007; Andrews-Speed 2012). There was also an unusual but valuable study on the change in corporate governance of China's major energy firms compared to the major international counterparts (Zhang 2004). A second set of studies under this first category also take a closer look at the evolution, domestic reserves, geographic bases, and import sources of oil and gas (Leung et al 2011; O'Hara and Lai 2011) as well as the development and prospects of nuclear energy (Thomson 2011). A third set of studies, which are frequently conducted, tends to be econometric in nature and explore the factors that affect energy consumption, efficiency, and structure in China's energy consumption (Kahrl and Roland-Holst 2009; Yuan et al 2008; Ma, Oxley, and Gibson 2009).

Regarding the second aforementioned topic, i.e., energy policies, the existing literature surveys the governance of energy, including institutions, policy making process, and regulation of the energy sector and the governmental reform of state energy firms in the recent decades (Kong 2010, 1-28; Andrews-Speed 2012; Andrews-Speed and Dannreuther 2011, 26-62; 97-112; Lin 2008). Studies on the third topic, namely, energy security in China, focus on oil and gas, the main energy resources that China heavily imports. These studies examine the formulation of China's international energy policy (Kong 2010, 29-60; 141-60; Andrews-Speed and Dannreuther 2011, 26-62; 97-112), China's energy diplomacy, strategic responses and international implications (Lai 2007; Kong 2010, 141-60; Zhao 2012), as well as specific issues such as overland and sea lane imports of China's energy sources and diplomatic and security implications (Downs 2006; Lai 2009). Though rich in empirical and historical analyses, there is an apparent lack of theoretical pursuit and tests in most of the existing literature. 
The studies in this special issue make three following contributions to the existing literature. First, a number of these studies employ a hypothesis-testing approach and aim to provide rigorous analysis of the empirical data and evidence. In developing the hypotheses, relevant theories are examined and applied to the Chinese energy sector. This attempt to apply theories to China's energy sector is particularly evident in the studies by Lai, O'hara and Wysoczanska (2015), Tyler (2015), Gress (2015), as well as those by Chen (2015) and Liao (2015). Lai et al (2015) scrutinise the validity of theories on internationalisation of firms from developing countries and find that sectoral strengths and to a lesser extent strategic assets seeking best explain major overseas investment of Chinese oil and gas firms. Next, Liao (2015) applies the principal-agent model to the interaction between the government and national energy firms and argues that the government has yet to become an effective principal. Their analyses and findings help advance the knowledge on the relevance of business theories for the Chinese energy sector. Tyler (2015), who casts his study in the theoretical context of corporate governance and state-business relations, cautions us against a rushed declaration of either an outright victory of marketization or a simple continuation of the command economy in China. Chen (2015), who takes up again the topic of state capitalism covered by Tyler (2015), examines the role of the state in producing competitive advantage, a concept critical in business theories, for Chinese solar PV firms at different stages of the development of these firms. Gress (2015) turns our attention to the role of local and global networks, another important concept in business studies, in the expansion of Chinese solar PV firms.

Second, a number of these studies in the special issue take into account the rapidly changing dynamics of energy in China in light of the global concerns with carbon emission and pollution in the recent decade. They investigate the prospects and transformation of China's energy sector toward a sustainable path of development. Evident examples include studies by Dent (2015) and by Thomson and Boey (2015) which survey the rapid growth of renewable energy and policy in this regard, by Wu et tal (2015), which examine carbon footprints across China's provinces and the underlying factors, as well as studies by Chen (2015) and Gress (2015), which examine the factors that contribute to the global ascent of China's solar industry.

Third, these studies try to capture recent development in China's energy sector and important features of China's energy sector, mostly notably, the increasingly internationalisation of the sector and growing linkages and networks of Chinese energy firms with global counterparts. Studies reflecting this last feature include Gress (2015), who studies the global networks of Chinese solar panel manufacturers, Lai et al (2015), who shed light on the rationale of major overseas investment deals of the two largest Chinese oil and gas firms, and Chen (2015) who investigates the role of governmental subsidies in the evolution of Chinese solar PV industry.

\section{Concluding Remarks}

It is therefore clear from the above discussion that China plays a pivotal role in the world global energy economy. As the implications of global warming sink in, the importance of what the PRC government does becomes more and more important. We hope that the readers of this Special Issue will find enough in the above cited research to enhance their understanding of what is at stake. 


\section{Bio-data}

HONGYI LAI is Associate Professor at the School of Contemporary Chinese Studies, Faculty of Social Sciences, University of Nottingham, UK. His research and multiple journal articles cover China's national and local reform strategies, regional development in China, as well as China's oil diplomacy and the internationalisation of its energy firms. His books relate to China's political economy include Asian Energy Security: The Maritime Dimension (London: Palgrave-MacMillan, 2009) and Reform and the Non-State Economy in China (London: Palgrave-MacMillan, 2006).

MALCOLM WARNER is Professor and Fellow Emeritus, Wolfson College, Cambridge and Judge Business School, University of Cambridge. He was the Editor-in-Chief, of the International Encyclopedia of Business and Management [IEBM], 8 volumes, (London: Thomson, 2002) and the author/editor of many books and articles on China. His latest work has recently been published: Understanding Management in China: Past, Present and Future, (London and New York, NY: Routledge, 2014). He is currently Co-Editor of the Asia Pacific Business Review.

\section{References}

Aoki, M. and Wu, J. (2012), The Chinese Economy: A New Transition, London and New York, NY: Palgrave Macmillan.

Andrews-Speed, P. (2012), The Governance of Energy in China: Transition to a Low-Carbon Economy, Houndmills and New York: Palgrave Macmillan.

Andrews-Speed, P. and Dannreuther, R. (2011), China, Oil and Global Politics. London and New York: Routledge.

Chen, G. 2015. “From Mercantile Strategy to Domestic Demand Stimulation: Changes in China's Solar PV Subsidies," Asia-Pacific Business Review, issue and page number to be inserted.

Dent, C. 2015. “China's Renewable Energy Development: Policy, Industry and Business Perspectives," Asia-Pacific Business Review, issue and page number to be inserted.

Downs, E. (2006), China's Quest for Energy Security, Santa Monica: Rank Corp.

Fan, J., Wu, Y., Guo, X., Zhao, D. and Marinova, D. (Wu et al.) 2015. "Regional Disparity of Embedded Carbon Footprint and Its Sources in China: A Consumption Perspective," Asia-Pacific Business Review, issue and page number to be inserted.

FT (Financial Times), 2014. "China Poised to Pass US as World's Leading Economic Power This Year," posted at http://www.ft.com/cms/s/0/d79ffff8-cfb7-11e3-9b2b-00144feabdc0.html\#ixzz34tjratYL [accessed April 30, 2014]. 
Gress, D., 2015. "Enrolling in Global Networks and Contingencies for China's Solar PV Industry," Asia-Pacific Business Review, issue and page number to be inserted.

IEA (International Energy Agency)(2007), World Energy Outlook 2007: China and India Insights. Paris: OECD.

Kahrl, F., and Roland-Holst, D. (2009), "Growth and Structural Change in China's Energy Economy," Energy, 34: 894-903.

Kong, B. (2010), China's International Petroleum Policy, Santa Barbara, Denver and Oxford: ABCCLIO.

Lai, H.H. (2007), "China's Oil Diplomacy: Is It a Global Security Threat?" Third World Quarterly, Vol. 28, No. 3: 519-38.

Lai, H. (2009), "Security of China's Energy Imports", in Lai, H. ed., Asian Energy Security: The Maritime Dimension. New York: Palgrave Macmillan, 49-77.

Lai, H., O'Hara, S., and Wysoczanska, K. 2015. "Rationale of internationalisation of China's NOCs: Natural or Strategic Resources Seeking?" Asia-Pacific Business Review, issue and page number to be inserted.

Leung, G., Li, R., and Low, M. (2011), "Transitions in China's Oil Economy, 1990-2010," Eurasian Geography and Economics, Vol. LII, No. 4 (July-August): 483-500.

Liao, J. X. 2015. "The Relationship between the Chinese Government and the National Oil Companies (NOCs): Who Is the Principal?" Asia-Pacific Business Review, issue and page number to be inserted.

Lin, K. C. (2008). "Macroeconomic Disequilibria and Enterprise Reform: Restructuring the Chinese oil and Petrochemical Industries in the 1990s," The China Journal, 60: 49-79.

Ma, H., Oxley, L., Gibson, J. (2009), "Substitution Possibilities and Determinants of Energy Intensity for China," Energy Policy 37: 1793-1804.

O'Hara, S. and Lai, H. (2011), “China's 'Dash for Gas': Challenges and Potential Impacts on Global Market," Eurasian Geography and Economics, Vol. LII, No. 4 (July-August): 501-22.

Rooker, T. 2015. "Corporate Governance or Governance by Corporates? Testing Governmentality in the Context of China's National Oil and Petrochemical Business Groups," Asia-Pacific Business Review, issue and page number to be inserted.

Thomson, E. (2011), "China's Nuclear Energy in Light of the Disaster in Japan", Eurasian Geography and Economics, Vol. LII, No. 4 (July-August): 464-82.

Thomson, E. and Boey, A. 2015. "The Role of Oil and Gas in China's Energy Strategy: An Overview," Asia-Pacific Business Review, issue and page number to be inserted.

Warner, M. (2014) Understanding Management in China: Past, Present and Future, London and New York, NY: Routledge. 
Yuan, J-H, Kang, J-G, Zhao, C-H, and Hu, Z-G, (2008), "Energy Consumption and Economic Growth: Evidence from China at Both Aggregated and Disaggregated Levels," Energy Economics, 30: 30773094.

Zhang, J. (2004), Catch-up and Competitiveness in China: The Case of Large Firms in the Oil Industry, London and New York: Routledge.

Zhao, S. ed. (2012), China's Search for Energy Security: Domestic Sources and International Implications. London and New York: Routledge.

END 